\title{
FRACTIONS AND TEMPORAL AND SPATIAL DISTRIBUTION OF PHOSPHORUS IN THE SEDIMENTS OF SANCHA LAKE
}

\author{
LI, Y. ${ }^{1 *}-$ ZHANG, J. Q. ${ }^{1}-$ GONG, Z. L. ${ }^{2}-$ FU, W. L. ${ }^{3}-$ WU, D. M. ${ }^{3}$ \\ ${ }^{I}$ Faculty of Geosciences and Environmental Engineering, Southwest Jiaotong University, \\ No. 111 North 1st Section, Erhuan Road, Chengdu, China \\ (phone: +86-135-1810-8466; fax: +86-028-8763-4616) \\ ${ }^{2}$ School of Food and Biological Engineering, Xihua University, Chengdu 610039, China \\ ${ }^{3}$ Jianyang Environmental Monitor Station, Jianyang, Sichuan 641400, China \\ *Corresponding author \\ e-mail: liyong@swjtu.edu.cn \\ (Received $22^{\text {nd }}$ Apr 2019; accepted $12^{\text {th }}$ Jul 2019)
}

\begin{abstract}
The fraction and distribution characteristics of phosphorus in the sediments of Sancha Lake were studied using the SMT Phosphorus fraction method and its influencing factors were discussed. According to the research results, total phosphorus (TP) content in the sediments was 270.00-3,722.80 $\mu \mathrm{g} \cdot \mathrm{g}^{-1}$, the organophosphorus (OP) content was $64.00-774.43 \mu \mathrm{g} \cdot \mathrm{g}^{-1}$, the inorganic phosphorus (IP) content, a main phosphorus fraction, was $164.00-3,006.99 \mu \mathrm{g} \cdot \mathrm{g}^{-1}$, accounting for about $69.32 \%$ of TP, the HCl-P content, a main phosphorus fraction of IP, was 125.00-2,474.04 $\mu \mathrm{g} \cdot \mathrm{g}^{-1}$, accounting for about $69.19 \%$ of IP, and the $\mathrm{NaOH}-\mathrm{P}$ content was less, i.e. 51.00-689.72 $\mu \mathrm{g} \cdot \mathrm{g}^{-1}$, accounting for about $30.73 \%$ of IP. Different phosphorus fractions had obvious temporal and spatial variation; all the sampling sites showed a general trend where the phosphorus fraction content was higher in winter and lower in summer, similar in spring and autumn. The content of organic matter in the sediments had significant correlation with $\mathrm{OP}, \mathrm{NaOH}-\mathrm{P}$ had significant correlation with $\mathrm{Fe}$ in the sediments, between $\mathrm{HCl}-\mathrm{P}$ in the sediments had significant correlation with $\mathrm{Ca}$, APA had significant positive correlation with OP. However, the $\mathrm{pH}, \mathrm{TN}$, dissolved oxygen and temperature had no significant correlation with various phosphorus fractions.
\end{abstract}

Keywords: phosphorus fractions, spatial and temporal distribution, sediment, Sancha Lake, eutrophication

\section{Introduction}

Phosphorus is the main restrictive factor (Zhang et al., 2012) of Lake Eutrophication, and most phosphorus nutrient salt entering into lakes will eventually be stored in the sediments under various conditions, forming endogenous pollution (Zhu et al., 2004). The fraction of phosphorus in the sediment has an important effect on its migration and transformation mechanism (Fan et al., 2010; Hupfer et al., 1995; Chuai et al., 2014; Li et al., 2014). The distribution characteristics of phosphorus in the sediments have already been confirmed to have a direct relation to the internal load of the lake, and different fractions and contents of phosphorus in the sediments play different roles in Lake Eutrophication (Yang et al., 2013; Zhou et al., 2013). Therefore, the analysis of different fractions of phosphorus in the sediments of a lake and their temporal and spatial distribution characteristics is of great significance to further research Lake Eutrophication. This paper mainly studied the fractions, contents, temporal and spatial distribution of phosphorus in the sediments of Sancha Lake, and discussed the factors influencing the content distribution of each phosphorus fraction, so as to provide data and theoretical support for further research on the mechanisms of lake eutrophication of Sancha Lake. 


\section{Materials and methods}

\section{Brief introduction to study area}

Sancha Lake is located in Tianfu New Area of Sichuan Province, east longitude $104^{\circ} 11^{\prime} 16^{\prime \prime}$ to $104^{\circ} 17^{\prime} 16^{\prime \prime}$, north latitude $30^{\circ} 13^{\prime} 08^{\prime \prime}$ to $30^{\circ} 19^{\prime} 56^{\prime \prime}$, its average depth is $8.3 \mathrm{~m}$, and the maximum depth is $32.5 \mathrm{~m}$. The area is under subtropical moist monsoon climate, the annual average temperature is 15.2 to $16.9{ }^{\circ} \mathrm{C}$, and the annual average rainfall is $786.5 \mathrm{~mm}$. Sancha Lake water mainly derives from the Minjiang River which accounts for about $80 \%$, and the rest of about $20 \%$ comes from the rainfall and two streams (Tiaodeng River and Longyun River). The drainage area above the dam site is $161.25 \mathrm{~km}^{2}$, the average runoff depth is $275.1 \mathrm{~mm}$, and the average sediment discharge through surface runoff is 200,000 t. Sancha Lake and its surrounding are an important part of "International Tourism Culture Area with Two Lakes and One Mountain" in Tianfu New Area. Sancha Lake is the source of drinking water for population in Sancha Town. Moreover, it can maintain biodiversity, store water, prevent and control flood, and adjust surface runoff and climate. According to the characteristics of lake and different human activities, Sancha Lake is divided into five functional areas as shown in Figure 1: (I) Main runoff area of lake; (II) Highly dense area of original cage culture; (III) Adjacent human activity intensive area; (IV) Relatively dense area of enclosure culture of Dahu Lake; (V) Tail water area of reservoir. According to the monitoring results of many years, the $\mathrm{COD}_{\mathrm{Cr}}$ and $\mathrm{BOD}_{5}$ of the waters of Sancha Lake decline year by year, while TN and TP have been rising, the corresponding chlorophyll increases year by year while transparency declines year by year, showing that the eutrophication has been formed in Sancha Lake (Li, et al., 2019).

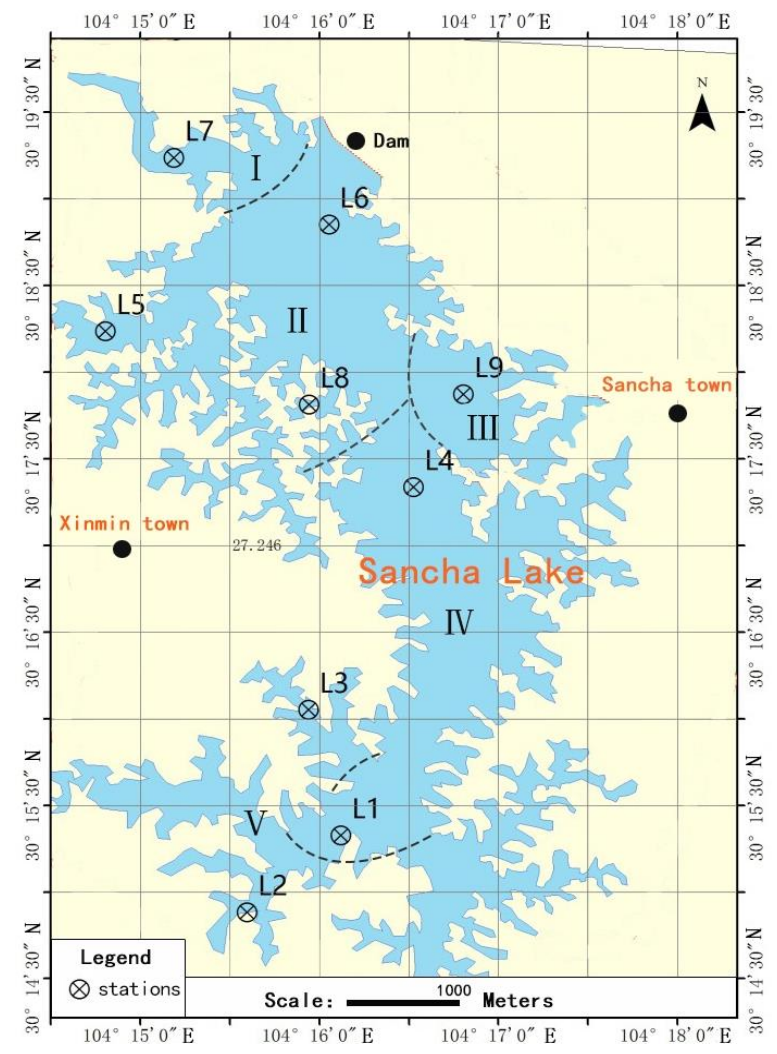

Figure 1. Sampling sites in the Sancha Lake 


\section{Sample collection and pretreatment}

According to the distribution characteristics of the sediments of Sancha Lake and eutrophication status (Jia et al., 2013), 9 sampling sites as shown in Figure 1 were selected, and the latitude and longitude of sampling sites were determined by GPS. In January (winter), April (spring), August (summer) and November (autumn) of 2016, the surface sediment at the bottom of Sanch Lake at each sampling site was collected using a grab bucket, then the surface sediment $(0-5 \mathrm{~cm})$ was collected using a organic glass column and placed in a clean sealed polyethylene bag. Three parallel samples of each sampling site were collected and mixed as the representative sample of such sampling site, and then they were stored in an ice box at $4{ }^{\circ} \mathrm{C}$ and brought back to the lab. One part of the sediment samples was immediately used for isolation of microbes and counting cultivation experiment, and the other part was grinded using a 100-mesh screen after freeze drying, and then packed in a sealed bag for the determination of phosphorus fraction and its physicochemical properties. Meanwhile, the overlying water at the bottom of the sediments of each sampling site was collected using an airtight water sampler for analysis of the index of water environment.

\section{Determination method}

The various fractions of phosphorus in the sediments were determined using the SMT chemical continuous extraction method (Ruban et al., 1999, 2001) recommended by European Standards Committee. The contents of TP, IP, OP, NaOH-P and HCl-P in the sediments were determined using the ammonium molybdate spectrophotometric method (Huang et al., 2003) Three parallel samples were determined for each fraction and then their average value was selected. Alkaline phosphatase activity (APA) was determined using the Anupama method (Anupama et al., 2008). The alkaline phosphatase can catalyze and hydrolyze $\mathrm{p}$-nitrophenyl phosphate $(\mathrm{p}-\mathrm{NPP})$ to produce steady yellow p-nitrophenol (PNP). Therefore, the production rate of PNP was measured using the colorimetric method, as an index of alkaline phosphatase activity (APA). The specific methods were as follows: Firstly, about $0.5 \mathrm{~g}$ of wet sediments was selected and placed in a sterilized reaction tube, then $10 \mathrm{ml}$ of Tris- $\mathrm{HCl}$ buffer with the $\mathrm{pH}$ of 8.4 and $0.5 \mathrm{~mol} \cdot \mathrm{L}^{-1}$ concentration was added to the tube and blended well at $37{ }^{\circ} \mathrm{C}$ for $1 \mathrm{~h}$ of reaction, then $2 \mathrm{ml}$ of $\mathrm{NaOH}$ solution with $1 \mathrm{~mol} / \mathrm{L}$ concentration was added to terminate the reaction, supernatant was filtered by centrifugation, $600 \mathrm{~nm}$ of solution was selected for colorimetric determination and the result was converted into the activity of dried mud of unit mass, and the PNP solution with different concentration was used to made the standard curve.

Total organic carbon (TOC) in the sediments was determined as per the regulations of On the Determination of Total Organic Carbon in Sediments issued by Chinese GB/T 19145-2003 (General Administration of Quality Supervision, Inspection and Quarantine of China, 2003). The $\mathrm{Fe}, \mathrm{Al}$ and $\mathrm{Ca}$ were determined as per the regulations of Monitoring and Distinguishing Method for Water and Wastewater issued by National Environmental Protection Bureau (State Environmental Protection Administration of China, 2002). The moisture content was determined using the weight-loss method, namely the sediment was put at $105^{\circ} \mathrm{C}$ and dried to constant weight. The $\mathrm{pH}$, temperature and electrical conductivity of the overlying water were determined using an HI991301 portable multi-parameter temperature meter, and the dissolved oxygen was determined using an HQ3OD portable dissolved oxygen meter. 


\section{Data analysis}

Data analysis was conducted by Excel 2003 software and SPSS19.0. Correlation analysis was conducted using the Pearson correlation analysis to determine the relationship between fractions of phosphorus in the sediments and physicochemical properties.

\section{Results}

\section{Physicochemical properties of the sediments and overlying water}

The $\mathrm{pH}$ of the overlying water ranged from 7.15 to 8.73 , averaging $7.53,7.25,7.91$ and 8.54 in spring, summer, autumn and winter, respectively, alkaline in winter and weakly alkaline in spring, summer and autumn; the temperature ranged from $11.1^{\circ} \mathrm{C}$ to $27.6^{\circ} \mathrm{C}$, averaging $18.90{ }^{\circ} \mathrm{C}, 26.0^{\circ} \mathrm{C}, 20.9{ }^{\circ} \mathrm{C}$ and $13.2^{\circ} \mathrm{C}$ in spring, summer, autumn and winter, respectively, with a temperature difference of about $13{ }^{\circ} \mathrm{C}$ in winter and summer, and not obvious temperature difference in spring and autumn; the DO ranged from 4.10 to $9.90 \mathrm{mg} \cdot \mathrm{L}^{-1}$, averaging $6.57 \mathrm{mg} \cdot \mathrm{L}^{-1}, 4.60 \mathrm{mg} \cdot \mathrm{L}^{-1}, 6.45 \mathrm{mg} \cdot \mathrm{L}^{-1}$ and $9.42 \mathrm{mg} \cdot \mathrm{L}^{-1}$ in spring, summer, autumn and winter, respectively, like temperature, it had huge temperature difference in winter and summer, and not obvious temperature difference in spring and autumn. The content of moisture in the sediments ranged from $55.47 \%$ to $82.7 \%$, averaging $73.48 \%, 70.42 \%, 73.14 \%$ and $73.46 \%$ in spring, summer, autumn and winter, respectively, changing slightly in the four seasons; the TOC in the sediments ranged from 13.7 to $36.3 \mathrm{mg} \cdot \mathrm{g}^{-1}$, averaging $23.3 \mathrm{mg} \cdot \mathrm{g}^{-1}, 27.68 \mathrm{mg} \cdot \mathrm{g}^{-1}$, $23.71 \mathrm{mg} \cdot \mathrm{g}^{-1}$ and $22.4 \mathrm{mg} \cdot \mathrm{g}^{-1}$ in spring, summer, autumn and winter, respectively, higher in summer and lower in winter, similar in spring and autumn; the TN in the sediments ranged from 1.2 to $3.1 \mathrm{mg} \cdot \mathrm{g}^{-1}$, averaging $1.92 \mathrm{mg} \cdot \mathrm{g}^{-1}, 2.57 \mathrm{mg} \cdot \mathrm{g}^{-1}$, $2.04 \mathrm{mg} \cdot \mathrm{g}^{-1}$ and $1.73 \mathrm{mg} \cdot \mathrm{g}^{-1}$ in spring, summer, autumn and winter, respectively, as with the variation laws of the TOC, it was higher in summer and lower in winter, similar in spring and autumn; the Fe in the sediments ranged from 25 to $128.4 \mathrm{mg} \cdot \mathrm{g}^{-1}$, averaging $43.93 \mathrm{mg} \cdot \mathrm{g}^{-1}, 37.98 \mathrm{mg} \cdot \mathrm{g}^{-1}, 47.33 \mathrm{mg} \cdot \mathrm{g}^{-1}$ and $61.46 \mathrm{mg} \cdot \mathrm{g}^{-1}$ in spring, summer, autumn and winter, respectively; the $\mathrm{Al}$ in the sediments ranged from 4.72 to $21.67 \mathrm{mg} \cdot \mathrm{g}^{-1}$, averaging $10.94 \mathrm{mg} \cdot \mathrm{g}^{-1}, 10.38 \mathrm{mg} \cdot \mathrm{g}^{-1}, 11.22 \mathrm{mg} \cdot \mathrm{g}^{-1}$ and $13.43 \mathrm{mg} \cdot \mathrm{g}^{-1} \mathrm{in}$ spring, summer, autumn and winter, respectively; the $\mathrm{Ca}$ in the sediments ranged from 7.20 to $59.9 \mathrm{mg} \cdot \mathrm{g}^{-1}$, averaging $32.74 \mathrm{mg} \cdot \mathrm{g}^{-1}, 32.86 \mathrm{mg} \cdot \mathrm{g}^{-1}, 37.34 \mathrm{mg} \cdot \mathrm{g}^{-1}$ and $35.39 \mathrm{mg} \cdot \mathrm{g}^{-1}$ in spring, summer, autumn and winter, respectively. From the seasonal variation of contents of $\mathrm{Fe}, \mathrm{Al}, \mathrm{Ca}$ in the sediments, it can be seen that the $\mathrm{Fe}$ content varied significantly in summer compared with winter, while the $\mathrm{Al}$ and $\mathrm{Ca}$ contents did not vary significantly with the seasons.

\section{Temporal and spatial variation of content of phosphorus in the sediments}

\section{Content and distribution characteristics of TP in the sediments}

As shown in Table 1, the content of TP in the sediments averaged 504.00$2,380.00 \mu \mathrm{g} \cdot \mathrm{g}^{-1}, \quad 270.00-1,376.00 \mu \mathrm{g} \cdot \mathrm{g}^{-1}, \quad 543.00-2,436.00 \mu \mathrm{g} \cdot \mathrm{g}^{-1} \quad \mathrm{~b}$ and 688.70 $3722.80 \mu \mathrm{g} \cdot \mathrm{g}^{-1}$ in spring, summer, autumn and winter, respectively, highest in winter, followed by spring and autumn, and lowest in winter, which was higher than Poyang Lake $\left(689.34 \mu \mathrm{g} \cdot \mathrm{g}^{-1}\right)$, Yao Lake $\left(987.93 \mu \mathrm{g} \cdot \mathrm{g}^{-1}\right)$ and Guanting Reservoir $\left(1,268.93 \mu \mathrm{g} \cdot \mathrm{g}^{-1}\right)$ (Xiang et al., 2010; Jiang et al., 2016; Li et al., 2005), and higher when compared with 
other similar lakes. From Figure 2 it can be seen that different sampling sites had significantly different TP content and the same sampling site had significantly different TP content in different seasons, all the sampling sites showed a general trend where the phosphorus fraction content was higher in winter and lower in summer, similar in spring and autumn, which was due to the fact that vigorous growth of plankton of the waters had great demand for phosphorus in summer and the plankton of the waters conducted excessive decomposition of phosphorus in the sediments in the absence of phosphorus of the waters (Xie et al., 2003). The content of TP in L8, L6 and L5 of the highly dense area of original cage culture and L9 of the adjacent human activity intensive area was high, of which, it was highest in L8 and L9, reaching 3,723 $\mu \mathrm{g}^{\mathrm{g}} \mathrm{g}^{-1}$ in L8 in winter; the content of TP in L4 and L1 of the relatively dense area of enclosure culture of Dahu Lake was relatively high, reaching $1,200 \mu \mathrm{g} \cdot \mathrm{g}^{-1}$ in winter; the content of TP in L7 of the main runoff area of lake and L2 and L3 of the tail water area of reservoir was low compared with other sampling sites, of which, the content of TP averaged $643 \mu \mathrm{g} \cdot \mathrm{g}^{-1}$ in L2, a sampling site with minimum pollution, which belongs to a moderately polluted area in accordance with EPA standard.

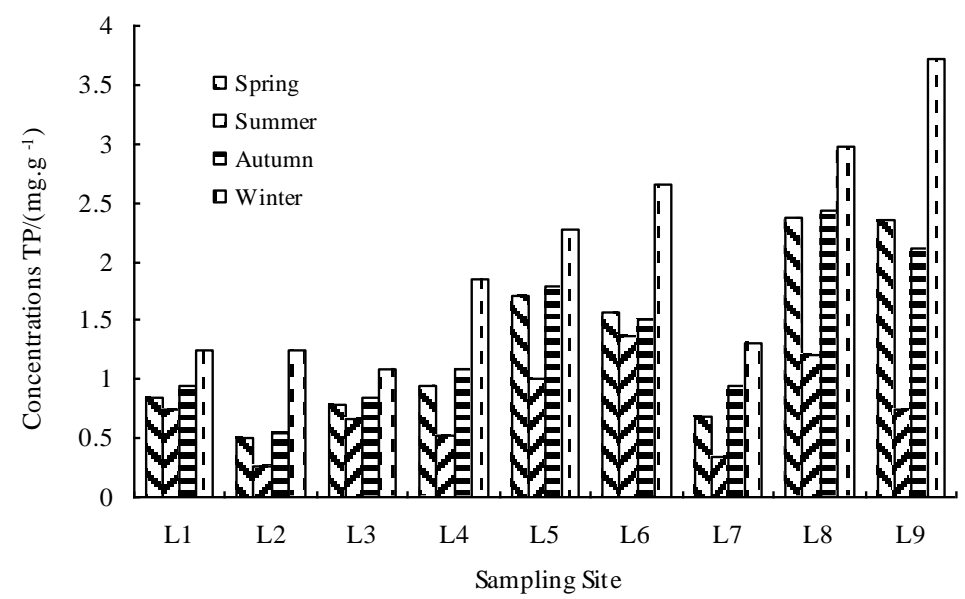

Figure 2. Seasonal variation of content of TP in different sampling sites

\section{Content and distribution characteristics of IP in the sediments}

As shown in Table 1, the IP content was 431.00-1,627.00 $\mu \mathrm{g} \cdot \mathrm{g}^{-1}, 164.00$ $900.00 \mu \mathrm{g} \cdot \mathrm{g}^{-1}, 291.00-1,568.00 \mu \mathrm{g} \cdot \mathrm{g}^{-1}$ and $531.95-3,006.99 \mu \mathrm{g} \cdot \mathrm{g}^{-1}$ in spring, summer, autumn and winter, respectively, accounting for about $69.32 \%$ of TP, thus IP was the main factor influencing the TP variation. IP mainly included two phosphorus fractions namely $\mathrm{NaOH}-\mathrm{P}$ and $\mathrm{HCl}-\mathrm{P}$, presenting $\mathrm{HCl}-\mathrm{P}>\mathrm{NaOH}-\mathrm{P}$ in spring, summer, autumn and winter, showing that HCl-P was the main factor influencing the IP variation. As shown in Table 2, the correlation analysis indicated that there was significant correlation between IP and TP $(P<0.01)$. As shown in Figure 3, the spatial distribution of IP in spring, summer, autumn and winter was similar to that of TP, with basically same high value point, except for L5 and L6 in which the IP content of L5 was higher than that of L6. Table 1 showed that the $\mathrm{NaOH}-\mathrm{P}$ content was $144.00-592.00 \mu \mathrm{g} \cdot \mathrm{g}^{-1}$, 51.00-371.00 $\mu \mathrm{g} \cdot \mathrm{g}^{-1}, 168.00-504.00 \mu \mathrm{g} \cdot \mathrm{g}^{-1}$ and 197.02-689.72 $\mu \mathrm{g} \cdot \mathrm{g}^{-1}$ in spring, summer, autumn and winter, respectively, averaging $32.84 \%$, 38.64\%, $36.44 \%$ and $27.00 \%$ of IP, respectively, changing slightly in summer and autumn, and low in winter may be due to 
the fact that weak reduction condition was favorable for NaOH-P to release to the overlying water on account of low oxygen content in the waters. In the spatial distribution, as shown in Figure 3, the content of NaOH-P in the sediments of $\mathrm{L} 9$ of the adjacent human activity intensive area was high, followed by L8, L6 and L5 of the highly dense area of original cage culture, and similar to TP in spatial distribution in other sampling sites in spring, summer, autumn and winter. The HCl-P content was 234.00-1,433.00 $\mu \mathrm{g} \cdot \mathrm{g}^{-1}, 125.00-545.00 \mu \mathrm{g} \cdot \mathrm{g}^{-1}, 278.00-1,063.00 \mu \mathrm{g} \cdot \mathrm{g}^{-1}$ and 330.98$2,474.04 \mu \mathrm{g} \cdot \mathrm{g}^{-1}$ in spring, summer, autumn and winter, respectively, averaging $71.33 .00 \%, 63.17 \%, 69.52 \%$ and $76.74 \%$ of IP, respectively, thus HCl-P was the main constituent of IP, changing slightly in summer and autumn, highest in winter, and low in summer may be due to the fact that the microorganism activity was highly favorable for $\mathrm{HCl}-\mathrm{P}$ to release to the overlying water, showing the characteristics (Lau et al., 2002) of the sediments in eutrophic lakes. As shown in spatial distribution diagram 5, the HCl-P content was similar to TP in spatial distribution in spring, summer, autumn and winter, with basically same high value point.

Table 1. Variation of phosphorus fractions in the sediments

\begin{tabular}{|c|c|c|c|c|c|c|}
\hline & \multicolumn{3}{|c|}{ Spring } & \multicolumn{3}{|c|}{ Summer } \\
\hline & $\begin{array}{l}\text { Variation range } \\
\left(\mu \mathrm{g} \cdot \mathrm{g}^{-1}\right)\end{array}$ & $\begin{array}{c}\text { Average } \\
\text { value } \pm \text { standard } \\
\text { deviation } \\
\left(\mu \mathrm{g} \cdot \mathrm{g}^{-1}\right) \\
\end{array}$ & $\begin{array}{l}\text { Variation } \\
\text { factor } \\
\left(\mu \mathrm{g} \cdot \mathrm{g}^{-1}\right)\end{array}$ & $\begin{array}{c}\text { Variation range } \\
\left(\mu \mathrm{g} \cdot \mathrm{g}^{-1}\right)\end{array}$ & $\begin{array}{c}\text { Average } \\
\text { value } \pm \text { standard } \\
\text { deviation } \\
\left(\mu \mathrm{g} \cdot \mathrm{g}^{-1}\right)\end{array}$ & $\begin{array}{c}\text { Variation } \\
\text { factor } \\
\left(\mu \mathrm{g} \cdot \mathrm{g}^{-1}\right)\end{array}$ \\
\hline $\mathrm{TP}$ & $504.00-2380.00$ & $1304.39 \pm 720.85$ & 0.55 & $270.00-1376.00$ & $762.01 \pm 377.15$ & 0.49 \\
\hline IP & $431.00-1627.00$ & $903.72 \pm 455.50$ & 0.50 & $164.00-900.00$ & $533.01 \pm 269.50$ & 0.51 \\
\hline $\mathrm{OP}$ & $110.00-848.00$ & $399.26 \pm 245.48$ & 0.61 & $64.00-360.00$ & $230.00 \pm 113.09$ & 0.49 \\
\hline $\mathrm{NaOH}-\mathrm{P}$ & $144.00-592.00$ & $296.61 \pm 154.20$ & 0.52 & $51.00-371.00$ & $205.98 \pm 110.45$ & 0.54 \\
\hline \multirow[t]{3}{*}{ HCl-P } & 234.00-1433.00 & $644.69 \pm 381.63$ & 0.59 & $125.00-545.00$ & $336.69 \pm 159.98$ & 0.48 \\
\hline & \multicolumn{3}{|c|}{ Autumn } & \multicolumn{3}{|c|}{ Winter } \\
\hline & $\begin{array}{l}\text { Variation range } \\
\quad\left(\mu \mathrm{g} \cdot \mathrm{g}^{-1}\right)\end{array}$ & $\begin{array}{c}\text { Average } \\
\text { value } \pm \text { standard } \\
\text { deviation } \\
\left(\mu \mathrm{g} \cdot \mathrm{g}^{-1}\right)\end{array}$ & $\begin{array}{l}\text { Variation } \\
\text { factor } \\
\left(\mu \mathrm{g} \cdot \mathrm{g}^{-1}\right)\end{array}$ & $\begin{array}{c}\text { Variation range } \\
\left(\mu \mathrm{g} \cdot \mathrm{g}^{-1}\right)\end{array}$ & $\begin{array}{c}\text { Average } \\
\text { value } \pm \text { standard } \\
\text { deviation } \\
\left(\mu \mathrm{g} \cdot \mathrm{g}^{-1}\right)\end{array}$ & $\begin{array}{c}\text { Variation } \\
\text { factor } \\
\left(\mu \mathrm{g} \cdot \mathrm{g}^{-1}\right)\end{array}$ \\
\hline $\mathrm{TP}$ & $543.00-2436.00$ & $1352 . .88 \pm 638.53$ & 0.47 & $688.70-3722.80$ & $1977.31 \pm 1003.71$ & 0.51 \\
\hline IP & $291.00-1568.00$ & $866.12 \pm 452.74$ & 0.52 & 531.95-3006.99 & $1449.53 \pm 840.60$ & 0.58 \\
\hline $\mathrm{OP}$ & $172.00-868.00$ & $437.63 \pm 264.26$ & 0.60 & $177.15-774.43$ & $525.56 \pm 202.36$ & 0.38 \\
\hline $\mathrm{NaOH}-\mathrm{P}$ & $168.00-504.00$ & $315.61 \pm 141.87$ & 0.45 & $197.02-689.72$ & $393.15 \pm 193.08$ & 0.49 \\
\hline $\mathrm{HCl}-\mathrm{P}$ & 278.00-1063.00 & $602.42 \pm 296.86$ & 0.49 & $330.98-2474.04$ & $1112.07 \pm 698.38$ & 0.54 \\
\hline
\end{tabular}

Table 2. Coefficients of correlation between different phosphorus fractions in the sediments $(n=36)$

\begin{tabular}{c|c|c|c|c|c}
\hline & TP & OP & IP & HCl-P & NaOH-P \\
\hline TP & 1 & & & & \\
OP & $0.906^{* *}$ & 1 & & & \\
\hline IP & $0.598^{* *}$ & $-0.542^{* *}$ & 1 & & \\
HCl-P & $0.435^{*}$ & $-0.364 *$ & $0.462 * *$ & 1 & \\
NaOH-P & $0.414^{*}$ & -0.202 & 0.282 & $-0.722^{* *}$ & 1 \\
\hline
\end{tabular}

$* P<0.05 ; * * P<0.01$ 

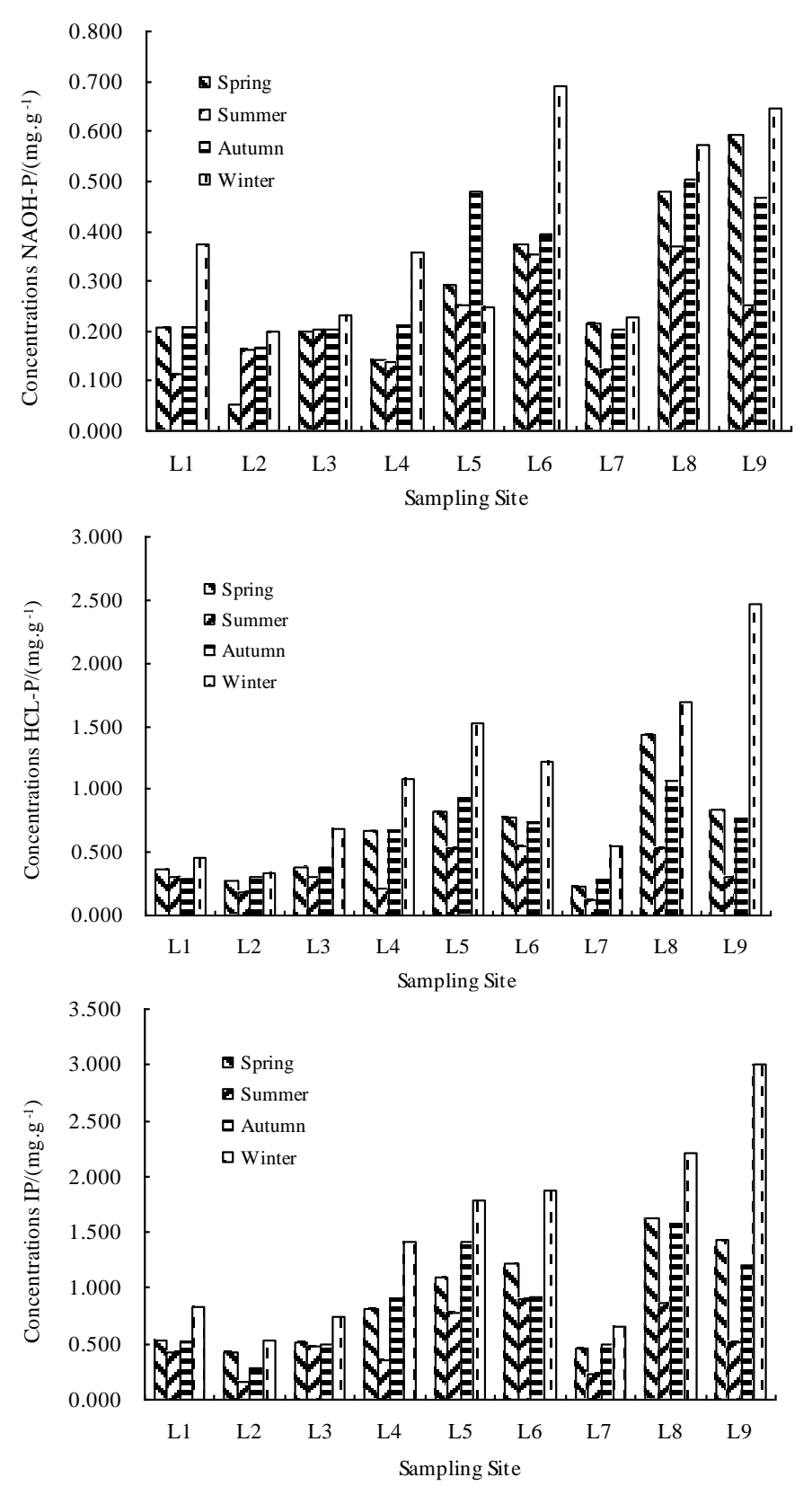

Figure 3. Seasonal variation of contents of $\mathrm{NaOH}-\mathrm{P}, \mathrm{HCl}-\mathrm{P}$ and IP in the sediments in different sampling sites

\section{Content and distribution characteristics of $O P$ in the sediments}

As shown in Table 1, the OP content was $110.00-848.00 \mu \mathrm{g} \cdot \mathrm{g}^{-1}, 64.00-360.00 \mu \mathrm{g} \cdot \mathrm{g}^{-1}$, $172.00-868.00 \mu \mathrm{g} \cdot \mathrm{g}^{-1}$ and $177.15-774.43 \mu \mathrm{g} \cdot \mathrm{g}^{-1}$ in spring, summer, autumn and winter, respectively, averaging $32.84 \%, 38.64 \%, 36.44 \%$ and $27.00 \%$ of TP, respectively, lower than IP of TP, however, the content of OP in the sediments was rich, higher than that of the same type of lakes such as Taihu, Chaohu and Longgan Lake (Fan, et al., 2007). As shown in spatial distribution Figure 4, in terms of OP content, L8 of the highly dense area of original cage culture and L9 of the adjacent human activity intensive area were high, L6 and L5 of the highly dense area of original cage culture were lower than that of L8 in the same area, L7 of the main runoff area of lake was higher than L4 of the 
relatively dense area of enclosure culture of Dahu Lake, which may be due to the fact that the organic matter was deposited in this area, and L2 and L3 of the tail water area of reservoir were the lowest. Furthermore, like TP, all the sampling sites showed a general trend where the phosphorus fraction content was higher in winter and lower in summer, similar in spring and autumn.

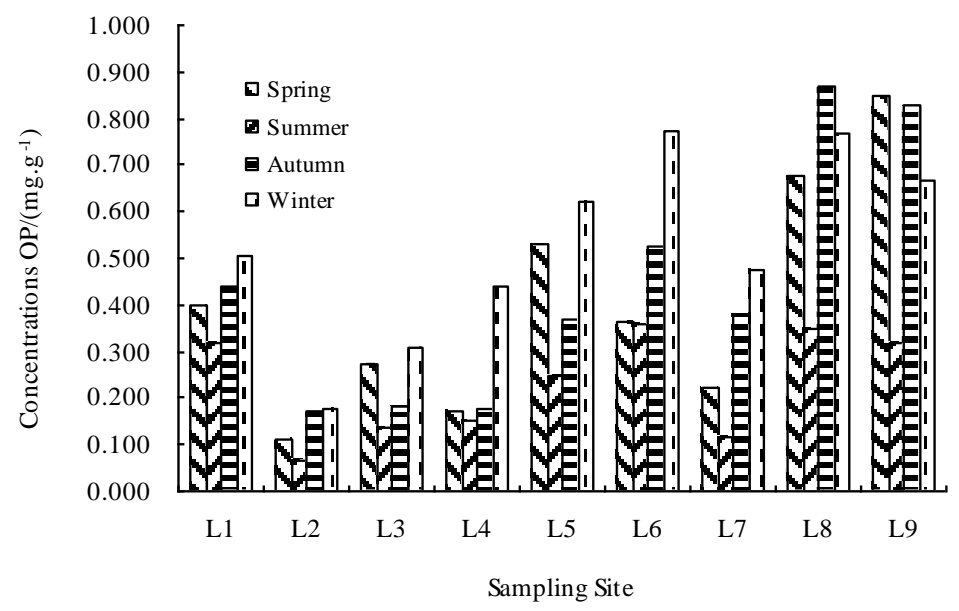

Figure 4. Seasonal variation of content of $O P$ in the sediments in different sampling sites

\section{Temporal and spatial variation of alkaline phosphatase in the sediments}

The alkaline phosphatase (APA) in the sediments ranged from 1.40 to $9.80 \mu \mathrm{mol} \cdot \mathrm{g}^{-1} \cdot \mathrm{h}^{-1}$, averaging $5.63 \mu \mathrm{mol} \cdot \mathrm{g}^{-1} \cdot \mathrm{h}^{-1}, 6.86 \mu \mathrm{mol} \cdot \mathrm{g}^{-1} \cdot \mathrm{h}^{-1}, 5.89 \mu \mathrm{mol} \cdot \mathrm{g}^{-1} \cdot \mathrm{h}^{-1}$ and $4.17 \mu \mathrm{mol} \cdot \mathrm{g}^{-1} \cdot \mathrm{h}^{-1}$ in spring and summer autumn and winter, respectively. From Figure 5, it can be seen that the APA of different sampling sites in summer was higher than that in winter, and similar in spring and autumn. The study showed that the enzyme activity was high in summer due to high temperature and low in winter due to low temperature (Wilczek et al., 2005), and the temperature increase can increase the affinity between enzyme and substrate, thus leading to enzyme catalytic rate increase (Chróst and Rai, 1993); in addition, the metabolic rate of microorganism will increase with the increase of temperature and then induce the microorganism to produce more enzyme (Wallenstein et al., 2010), therefore, the APA in the study area showed obvious seasonal variation. In the spatial distribution of APA, like OP, L8, L6 and L5 of the highly dense area of original cage culture and L9 of the adjacent human activity intensive area were high, followed by L1 of the relatively dense area of enclosure culture, L7 of the main runoff area of lake was higher than L4 of the relatively dense area of enclosure culture of Dahu Lake, and L2 and L3 of the tail water area of reservoir were the lowest. It can be seen that the high APA of the highly dense area of original cage culture and the adjacent human activity intensive area indicated that the APA was closely related to the input of pollutants (Zhang et al., 2007), in culture dosing and human activity area, the more nutrients input, the more organic phosphorus or enzymatic hydrolysis phosphorus increase, thus inducing the higher APA, such a mechanism was known as the substrate inducing mechanism (Li et al., 2007). Therefore, APA can be used as an indicator of the degree of sediment pollution to a certain extent (Huang et al., 2013). By correlation analysis, it can be seen that the APA had a significant correlation $(P<0.05)$ with OP only in winter, while poor correlation with other phosphorus fractions. 


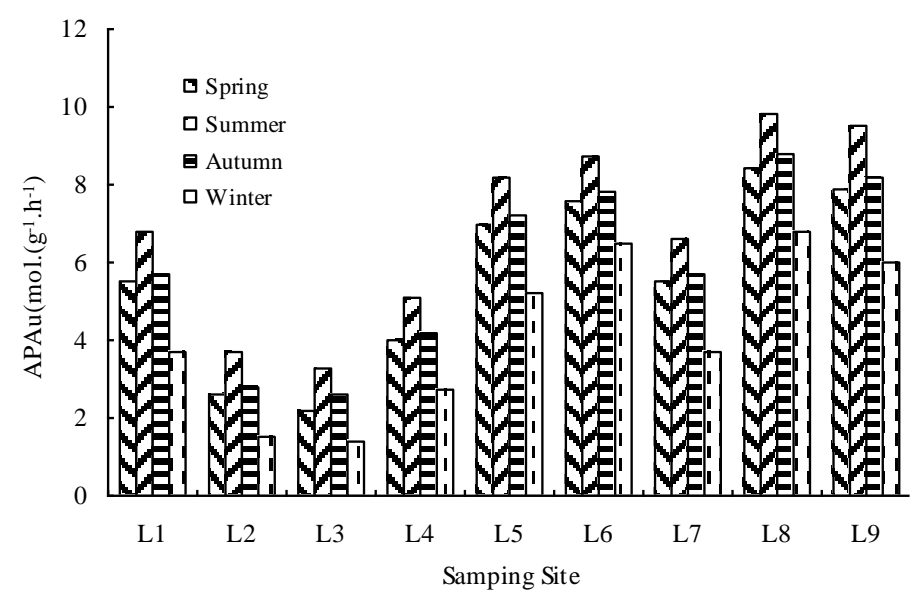

Figure 5. Seasonal variation of content of APA in the sediments in different sampling sites

\section{Discussion}

\section{Distribution characteristics of different phosphorus fractions in the sediments of Sancha Lake}

The phosphorus fractions in the sediments are closely related to the migration process of phosphorus to the overlying water, therefore, comprehending the distribution characteristics of different phosphorus fractions in the sediments has important practical significance to control the internal source pollution and reduce the endogenous phosphorus release. In this study, 9 sampling sites were selected as the representative samples of the sediments, and statistical analysis was conducted for the composition of different phosphorus fractions. The OP, NaOH-P and HCl-P in the sediments of Sancha Lake averaged $30 \%, 20.5 \%$ and $49.5 \%$ of TP, respectively, suggesting that HCl-P was the main constituent of phosphorus, followed by OP, while NaOH-P, mostly easily to release and with most biological activity, was the lowest. The decomposition of $\mathrm{NaOH}-$ $\mathrm{P}$ was closely related to the environmental conditions such as oxidation-reduction potential, while the morphological transformation and release process of $\mathrm{HCl}-\mathrm{P}$ and $\mathrm{OP}$ were mostly related to the microorganism. Previous studies have indicated that microorganism dissolves HCL-P by secretion of organic acid, while phosphatase secreted by microorganism is an indispensable mediator of OP degradation pathway (Wu and Zhou, 2005). Therefore, in the sediments of Sancha Lake that are rich in HCl$\mathrm{P}$ and OP, microorganism should play an important role in the migration and transformation process of phosphorus. The distribution characteristics of phosphorus fractions of different sampling sites were different, L8 of the highly dense area of original cage culture had high OP content, accounting for approximately $49 \%$ of TP, which was significantly higher than the average level of the whole lake, L9 of the adjacent human activity intensive area had high NaOH-P content, accounting for approximately $36 \%$ of TP, L6 and L5 of the highly dense area of original cage culture also had high OP content, averaging close to $40 \%, \mathrm{~L} 1$ and L4 of the relatively dense area of enclosure culture of Dahu Lake had low OP and NaOH-P contents, but high absolute content of HCl-P, which may be due to the fact that the fish of the upper water consumed and absorbed the phosphorus of the waters in the growth process, thus promoting the release of OP and NaOH-P in the sediments, and L2 and L3 of the tail water area of reservoir had low $\mathrm{OP}, \mathrm{NaOH}-\mathrm{P}$ and $\mathrm{HCl}-\mathrm{P}$ contents on account of little 
water flow and low pollution. Since $\mathrm{OP}$ and $\mathrm{NaOH}-\mathrm{P}$ were phosphorus with release potential, so L8 and L9 had the most endogenous phosphorus release potential, meanwhile, L6, L5, L4 and L1 could exhibit strong phosphorus release capability under appropriate environmental conditions such as high temperature and hypoxia.

\section{Correlation between different phosphorus fractions in the sediments of Sancha Lake}

Correlation between different phosphorus fractions in the sediments of Sancha Lake was as shown in Table 2. TP had significant correlation with four phosphorus fractions, among which, the coefficient of correlation between TP and OP was higher, presenting extremely significant correlation, suggesting that the variation of content of TP in the sediments of Sancha Lake was closely related to OP fluctuation. IP had extremely significant correlation with $\mathrm{HCl}-\mathrm{P}$ and positive correlation with $\mathrm{NaOH}-\mathrm{P}$, but not significant correlation, which may be due to the fact that the microbial activity was highly favorable for HCl-P to release to overlying water. IP had extremely significant negative correlation with $\mathrm{OP}$, suggesting a presence of mutual transformation between IP and OP. HCl-P had significant negative correlation with OP, suggesting that the orthophosphate released from decomposition of these two phosphorus fractions may transform towards fraction of each other under suitable environmental conditions. Furthermore, there was significant negative correlation between $\mathrm{HCl}-\mathrm{P}$ and $\mathrm{NaOH}-\mathrm{P}$, two main phosphorus fractions of IP.

\section{Correlation between different phosphorus fractions in the sediments of Sancha Lake and physiochemical factors}

Correlation between different phosphorus fractions in the sediments of Sancha Lake and physiochemical factors was shown in Table 3. Based on isothermy, Zhou et al. (2005) discovered, after investigating the sediments of Taihu Lake, that the influence of $\mathrm{pH}$ on phosphorus adsorption was an inverted "U" shape, and positive correlation on phosphorus analysis. the $\mathrm{pH}$ of the sediments of Sancha Lake was neutral leaning alkalinity, i.e. weakly alkaline in the four seasons, and had significant correlation with $\mathrm{HCl}-\mathrm{P}$ phosphorus fractions, while the content of organic matter in the sediments had significant correlation with OP, such similar laws were also found by Huang et al. (2005) in studies on lake and reservoir. $\mathrm{NaOH}-\mathrm{P}$ had significant correlation with the content of $\mathrm{Fe}$ in the sediments, whose formation was closely related to the adsorption and binding of iron and aluminum compounds, $\mathrm{HCl}-\mathrm{P}$ in the sediments had extremely significant correlation with Ca. APA had extremely significant positive correlation with TP and OP and significant positive correlation with IP, which was basically in agreement with the results of a study by Jiang et al. (2011), who concluded that the APA had significant correlation with TP, IP and OP in the sediments. Other studies have suggested a complex relationship between APA and OP, and Xue et al. (1995) suggested that if the IP produced by enzymolysis of ALP was used by the biological organisms in the sediments, then the APA had positive correlation with OP; if the IP produced by enzymolysis of ALP moved upward into the overlying water, then the APA had negative correlation with OP. While Huang and Huang (1999) pointed out that the dissolved IP and small molecule OP concentration were the main factors influencing the APA variation because the APA jumped to high value when the dissolved IP or small molecule OP were almost depleted. Therefore, the relationship between the APA 
and phosphorus was uncertain, which may be associated with the biological effect, physicochemical conditions of the sedimentation and nutrient content.

In addition, the $\mathrm{TN}$, dissolved oxygen, temperature will also have an impact on the phosphorus fractions and phosphorus content, but their correlation was not significant, which may be related to water power, environmental media conditions and biological effect.

Table 3. Coefficients of correlation between different phosphorus fractions in the sediments and physicochemical properties $(n=36)$

\begin{tabular}{c|c|c|c|c|c|c|c|c|c}
\hline & TN & TOC & Fe & Al & Ca & PH & O2 & T & APA \\
\hline TP & -0.201 & -0.338 & 0.345 & 0.284 & $0.403^{*}$ & 0.020 & -0.131 & -0.147 & $0.466^{* *}$ \\
OP & 0.047 & $0.382^{*}$ & 0.331 & 0.196 & 0.291 & 0.051 & 0.184 & -0.37 & $0.596^{* *}$ \\
IP & 0.247 & 0.245 & 0.157 & 0.257 & $0.462^{* *}$ & -0.098 & -0.038 & -0.117 & $0.344^{*}$ \\
HCl-P & -0.236 & -0.082 & 0.282 & 0.185 & $0.749^{* *}$ & $-0.023^{*}$ & 0.072 & -0.089 & 0.0586 \\
NaOH-P & -0.200 & 0.012 & $0.430^{*}$ & $0.46^{*}$ & 0.281 & 0.133 & 0.256 & -0.269 & 0.054 \\
\hline
\end{tabular}

$* P<0.05 ; * * p<0.01$

\section{Conclusions}

(1) The content of TP in the sediments of Sancha Lake ranged from 504.00 to $2,380.00 \mu \mathrm{g} \cdot \mathrm{g}^{-1}, 270.00$ to $1,376.00 \mu \mathrm{g} \cdot \mathrm{g}^{-1}, 543.00$ to $2,436.00 \mu \mathrm{g} \cdot \mathrm{g}^{-1}$ and 688.70 to $3,722.80 \mu \mathrm{g} \cdot \mathrm{g}^{-1}$ in spring, summer, autumn and winter, respectively. The contents of all phosphorus fractions were highest in winter, followed by spring and autumn, and smallest in winter. In the four seasons IP was the main phosphorus fraction of TP, averaging about $69.52 \%$ of $\mathrm{TP}$, in which $\mathrm{HCl}-\mathrm{P}$ was the main phosphorus fraction, averaging $71.8 \%$ of IP, and OP averaged about $29.50 \%$ of TP.

(2) In the spatial distribution, different sampling sites had significantly different phosphorus fraction content and the same sampling site had significantly different phosphorus fraction content in different seasons, all the sampling sites showed a general trend where the phosphorus fraction content was higher in winter and lower in summer, similar in spring and autumn. The contents of all phosphorus fractions were basically same, high in the highly dense area of original cage culture and adjacent human activity intensive area, relatively high in the relatively dense area of enclosure culture of Dahu Lake, and low in the main runoff area of lake and tail water area of reservoir.

(3) Correlation analysis showed that the content distribution of phosphorus in the sediments was influenced by many factors in the sedimentary environment, exhibiting different correlation in different seasons. TP had extremely significant correlation with APA and significant correlation with $\mathrm{Ca}$, OP had extremely significant correlation with APA and significant correlation with TOC, HCl-P had extremely significant correlation with $\mathrm{Ca}, \mathrm{NaOH}-\mathrm{P}$ had significant correlation with $\mathrm{Ca}$ and $\mathrm{Al}$, IP had significant correlation with $\mathrm{Ca}$, and $\mathrm{pH}, \mathrm{TN}$ as well as dissolved oxygen and temperature of the overlying water will also influence the phosphorus fractions and phosphorus contents, but their correlation was not significant.

Acknowledgements. This research was funded by the Sichuan science and technology support project (2018GZ0416). 


\section{REFERENCES}

[1] Anupama, V. N., Amrutha, P. N., Chitra, G. S. (2008): Phosphatase activity in anaerobic bioreactors for wastewater treatment. - Water Research 42: 2796-2802.

[2] Chróst, R. J., Rai, H. (1993): Ectoenzyme activity and bacterial secondary production in nutrient-impoverished nutrient-enriched freshwater mesocosms. - Microbial Ecology 25(2): 131-150.

[3] Chuai, X., Yang, L., Cheng, S. (2014): Characteristics and influencing factors of phosphorus adsorption on sediment in Lake Taihu and Lake Hulun. - Environmental Science 35(3): 951-957.

[4] Fan, C. X., Wang, C. X. (2007): Lake Environmental Geochemistry and Eutrophication in Middle and Lower Yangtze River. - Science Press Publishing, Beijing, China.

[5] Fan, J., Wang, D., Zhang, K. (2010): Experimental study on a dynamic contaminant release into overlying water-body across sediment-water interface. - Journal of Hydrodynamics, Series B 22(5): 354-357.

[6] General Administration of Quality Supervision, Inspection and Quarantine of the People's Republic of China (AQSIQ) (2003): GB/T19145-2003 Determination of Total Organic Carbon in Sedimentary Rock. - Standards Press of China, Beijing.

[7] Huang, B., Huang, S. (1999): Regulation of dissolved phosphorus in the variety of alkaline phosphatase activity of marine microalgae. - Acta Oceanologica Sinica 21(1): 55-60.

[8] Huang, Q. H., Wang, D. H., Wang, C. X. (2003): Relation between phosphorus forms in the sediments and lake eutrophication. - China Environmental Science 23(6): 583-586.

[9] Huang, Q. H., Wang, Z. J., Wang, D. H., Wang, C. X., Ma, M., Jin, X. C. (2005): Origins and mobility of phosphorus forms in the sediments of lakes Taihu and Chaohu, China. Journal of Environmental Science and Health, Part A 40: 91-102.

[10] Huang, R., Wang, S., Zhao, H. (2013): Study on temporal and spatial variation of alkaline phosphatase activity in the surface sediments of Erhai Lake. - Research of Environmental Sciences 26(3): 250-255.

[11] Hupfer, H., Gachter, R., Giovanoli, R. (1995): Transformation of phosphorus species in settling seston and during early sediment diagenesis. - Aquatic Sciences 57(4): 305-324.

[12] Jia, B. Y., Tang, Y., Fu, W. L. (2013): Relationship among sediment characteristics, eutrophication process and human activities in the Sancha Lake. - China Environ. Sci. 33: 1638-1644.

[13] Jiang, J. M., Zhao, H., Shen, M. N. (2011): Distribution and impact factor of alkaline phosphatase activity in the intertidal surface sediments of the Yangtze Estuary. - Acta Scientiae Circumstantiae 31(10): 2233-2239.

[14] Jiang, L., Guan, G., Liao, C. (2016): Occurrence and spatial distribution of phosphorus in the sediments of the Yao Chi. - Chinese Journal of Environmental Engineering 10(5): 2756-2760.

[15] Lau, S. S. S., Lane, S. N. (2002): Biological and chemical factors influencing shallow lake eutrophication: a long-term study. - Science of the Total Environment 288: 167-181.

[16] Li, C., Yuan, H., Huang, H. (2005): The vertical distribution characteristics of phosphorus solubilizing bacteria in the sediment of Guanting Reservoir. - Science of China series D. Geoscience 35(Supplementary issue): 241-248.

[17] Li, C., Lu, J., Li, H. (2007): The landward changes of soil enzyme activities in a tidal flat wetland of the Yangtze River estuary and correlations with physico-chemical factors. Acta Ecologica Sinica 27(9): 3663-3669.

[18] Li, Q., Yin, J., Xi, B. (2014): Characteristics of organic phosphorus fractions in sediments of inflow rivers of Lake Chaohu, China. - Chinese Journal of Environmental Engineering 8(2): 441-447. 
[19] Li, Y., Zhang, J. Q., Gong, Z. L.(2019): Gcd gene diversity of quinoprotein glucose dehydrogenase in the sediment of Sancha Lake and its response to the environment. - Int. J. Environ. Res. Public Health 16: 1-18.

[20] Ruban, V., Srigault, S., Demare, D., Philippe, A. M. (1999): An investigation of the origin and mobility of phosphorus in freshwater sediments from Bort-Les-Orgues Reservoir, France. - Journal of Environmental Monitoring 1: 403-407.

[21] Ruban, V., López-Sánchez, J. F., Pardo, P. (2001): Harmonized protocol and certified reference material for the determination of extractable contents of phosphorus in freshwaer sediments. A synthesis of recent works. - Fresenius Journal of Analytical Chemistry 370(2/3): 224-228.

[22] State Environmental Protection Administration of China (2002): Water and Wastewater Monitoring and Analysis Method. - China Environmental Science Press, Beijing.

[23] Wallenstein, M., Allison, S. D., Ernakovich, J. (2010): Controls on the temperature sensitivity of soil enzymes: a key driver of in situ enzyme activity rates. - Soil Enzymology 22: 245-258.

[24] Wilczek, S., Fischer, H., Pusch, M. T. (2005): Regulation and seasonal dynamics of extracellular enzyme activities in the sediments of a large lowland river. - Microbial Ecology 50(2): 253-267.

[25] Wu, G. F., Zhou, X. P. (2005): Characterization of phosphorus-releasing bacteria in a small eutrophic shallow, eastern lake. - Water Research 39: 4623-4632.

[26] Xiang, S., Zhou, W. (2010): Occurrence and distribution of phosphorus in sediments of Poyang Lake. - Journal of Lake Science 22(5): 649-654.

[27] Xie, L. Q., Xie, P., Li, S. X., Tang, H. J. (2003): The low TN: TP ratio, a cause or a result of Microcystis blooms. - Water Research 37: 2073-2080.

[28] Xue, X., Hong, H., Huang, B. (1995): Distribution and dynamics of alkaline phosphatase activity and their relationship with various forms of phosphorus in the sediments of the Western sea of Xiamen. - Acta Oceanologica Sinica 17(5): 81-87.

[29] Yang, L., Tang, Z., Hao, Y. (2013): Morphometry of phosphorus in the lake sediments of Taihu by chemical sequential extraction method. - Global Geology 32(3): 634-639.

[30] Zhang, T., Wang, X., Jin, X. (2007): Vertical variation of alkaline phosphatase activity and phosphorus forms in the Taihu Lake sediment and the relationship between them. Journal of Agro-Environment Science 26(1): 36-40.

[31] Zhang, Z., Wang, Z., Holden, J. (2012): The release of phosphorus from sediment into water in subtropical wetlands: A warming microcosm experiment. - Hydrological Processes 26(1): 15-26.

[32] Zhou, A., Tang, H., Wang, D. (2005): Phosphorus adsorption on natural sediments: modeling and effects of $\mathrm{pH}$ and sediment composition. - Water Research 39(7): 12451254.

[33] Zhou, X., Guo, H., Zhang, J. (2013): Simulated study on phosphorus release from sediment in Changshou Lake influenced by environmental factors. - Chinese Journal of Environmental Engineer-ring 7(5): 1671-1675.

[34] Zhu, G., Qin, B., Gao, G. (2004): Fractionation of phosphorus in sediments and its relation with soluble phosphorus contents in shallow lakes located in the middle and lower reaches of Changjiang River, China. - Acta Scientiae Circumstantiae 24(3): 381388. 